Ni Kadek Devita Putri, I Gustri Agung Oka Negara, Ni Wayan Suniasih. (2020). Model Pembelajaran Think Talk Write Berbantuan Mind Mapping Terhadap Kompetensi Pengetahuan IPA. Jurnal Penelitian dan Pengembangan Pendidikan. Vol. 4 (3) pp. 417-425.

\title{
Model Pembelajaran Think Talk Write Berbantuan Mind Mapping Terhadap Kompetensi Pengetahuan IPA
}

\author{
Ni Kadek Devita Putri*, I Gusti Agung Oka Negara², Ni Wayan Suniasih ${ }^{3}$ \\ 123 Program Studi Pendidikan Guru Sekolah Dasar Universitas Pendidikan Ganesha
}

\begin{abstract}
Abstrak
Penelitian ini bertujuan untuk mengetahui pengaruh model pembelajaran Think Talk Write berbantuan Mind Mapping terhadap kompetensi pengetahuan IPA siswa kelas V SD. Penelitian ini merupakan penelitian eksperimen semu dengan rancangan non-equivalent post-test only control group design. Populasi dalam penelitian ini adalah seluruh kelas V SD sebanyak 146 siswa. Penentuan sampel menggunakan teknik random sampling. Sampel dalam penelitian ini adalah kelas V SD Negeri 2 Siangan sebanyak 25 siswa sebagai kelompok eksprimen dan kelas V SD Negeri 2 Sumita sebanyak 18 siswa sebagai kelompok kontrol. Metode pengumpulan data dalam penelitian ini yaitu metode tes, instrument tes pilihan ganda biasa. Data yang diperoleh $t_{h i t u n g}=3,5$ dan pada taraf signifikansi $5 \%$ dan $d k=n_{1}+n_{2}-2=41$ maka diperoleh nilai $t_{\text {tabel }}=2,021$, karena $t_{\text {hitung }}>t_{\text {tabel }}$ maka $H_{o}$ ditolak yang berarti terdapat perbedaan yang signifikan antara kelompok eksperimen dan kelompok kontrol. Nilai rata-rata kompetensi pengetahuan IPA siswa kelompok eksperimen $\bar{X}=83,16$ > kelompok kontrol $\bar{X}=65,06$. Dengan demikian dapat disimpulkan bahwa model pembelajaran Think Talk Write berbantuan Mind Mapping berpengaruh terhadap kompetensi pengetahuan IPA siswa kelas V SD. Berdasarkan hasil penelitian ini disarankan agar dijadikan sebagai kajian yang relevan untuk memperdalam teori mengenai model pembelajaran Think Talk Write berbantuan Mind Mapping.
\end{abstract}

\begin{abstract}
This study aims to determine the effect of Mind Talk Write learning model assisted by Mind Mapping on the science competence of fifth grade elementary school students. This research is a quasi-experimental study with a non-equivalent post-test only control group design. The population in this study were all grade $V$ elementary schools totaling 146 students. Determination of the sample using random sampling techniques. The sample in this study was the fifth grade SD Negeri 2 Siangan as many as 25 students as the experimental group and the fifth grade SD Negeri 2 Sumita as many as 18 students as the control group. Data collection methods in this study are the test method, the usual multiple choice test instrument. The data obtained tcount $=3.5$ and at a significance level of $5 \%$ and $d k=n 1+n 2-2=41$, the value of ttable $=2,021$ is obtained, because tcount $>$ ttable Ho is rejected which means that there are significant differences between the experimental and control groups. The average value of science knowledge competence of the experimental group students $\bar{X}_{=83.16>\text { control group }} \bar{X}_{=65.06}$. Thus it can be concluded that the Think Talk Write learning model aided by Mind Mapping affects the science knowledge competence of fifth grade elementary school students. Based on the results of this study it is suggested that it be used as a relevant study to deepen the theory of the Mind Mapping Learning Think Assisted learning model.
\end{abstract}

Kata Kunci:

Think talk write, mind mapping.

\section{Keywords:}

Think talk write, mind mapping.

\footnotetext{
* Corresponding author. 


\section{PENDAHULUAN}

Pendidikan di jenjang sekolah dasar merupakan pendidikan paling penting dan berguna pada perkembangan diri seorang peserta didik. Hal ini disebabkan SD merupakan sumber pendidikan dasar untuk seorang anak dalam rangka mendapatkan ilmu pengetahuan setelah anak di didik oleh kedua orang tua dan setelah meninggalkan taman kanak-kanak yakni lingkungan bermain dan belajar yang ada diluar rumah. Mahardita (2017) Pendidikan adalah segala pengaruh yang diupayakan sekolah terhadap anak dan remaja yang diserahkan kepadanya agar mempunyai kemampuan yang sempurna dan kesadaran penuh terhadap hubungan-hubungan dan tugas-tugas sosial mereka. Pendidikan menjadi pilar utama dalam mewujudkan perubahan manusia kearah yang positif dan menuju pencapaian potensi kemanusiaan tertinggi. Hal tersebut berarti bahwa pendidikan harus menjadi skala prioritas yang utama manusia agar manusia mempunyai arah dan tujuan yang jelas mengenai apa yang dikerjakan dan dipilih untuk memenuhi kebutuhan hidupnya. Aryastuti (2017) pendidikan bertujuan untuk mengembangkan segala potensi yang ada pada peserta didik agar nantinya dapat menciptakan generasi yang berkualitas yang berguna bagi masyarakat, bangsa dan negara. Untuk meningkatkan kualitas sumber daya manusia dan mencapai tujuan pendidikan nasional, pemerintah telah menyelenggarakan berbagai upaya. Dalam pendidikan mencakup dua konsep yang berhubungan yaitu belajar dan pembelajaran. Konsep belajar mencakup peserta didik sedangkan konsep pembelajaran berakar pada pihak pendidik. Tindakan atau usaha yang dirancang oleh pendidik untuk mendukung proses belajar peserta didik melalui kegiatankegiatan diartikan sebagai suatu proses pembelajaran. Dalam proses pembelajaran terjadi proses interaksi antara peserta didik dengan pendidik.

Kurikulum pendidikan di Indonesia selalu ada inovasi sesuai dengan globalisasi dan mempunyai tantangan untuk kemajuan Sumber Daya Manusia (SDM). Aryastuty (2017) Kurikulum yang pernah dipakai yaitu mulai dari Kurikulum Berbasis Kompetensi (KBK), Kurikulum Tingkat Satuan Pendidikan (KTSP) dan yang terbaru Kurikulum 2013. Salah satu tantangan nyata tersebut adalah pendidikan hendaknya mampu bersaing secara global. Oleh karena itu pengelolaan pendidikan harus berorientasi pada bagaimana menciptakan perubahan dan pengembangan mutu pendidikan di Indonesia, serta sebagai upaya telah dilaksanakan hampir di semua komponen pendidikan. Proses pembelajaran pada kurikulum 2013 untuk semua jenjang dilaksanakan dengan menggunakan pendekatan ilmiah (saintifik). Wiranata (2018) Pembelajaran dalam kurikulum 2013 menggunakan sistem tema (tematik integratif). Dimana dalam beberapa pertemuan siswa mempelajari beberapa muatan materi yang tergabung dalam satu tema. Tema merajut makna berbagai konsep dasar sehingga siswa tidak belajar secara parsial. Siswa dituntut melalui beberapa proses secara aktif mencari, mengolah, mengontruksi, dan menerapkan pengetahuan berdasarkan langkah-langkah pendekatan saintifik dalam kurikulum 2013. Maka sangat siperlukan upaya inovasi dari guru dalam mengreasikian pembelajaran di kelas agar kelihatan lebih menarik dan tidak membosankan. Dalam merancang suatu pembelajaran, harus memperhatikan tujuan diselenggarakannya pembelajaran itu sendiri, termasuk didalam pembelajaran Ilmu Pengetahuan Alam (IPA).

IPA merupakan salah satu cabang ilmu pengetahuan yang memegang peranan penting dalam perkembangan IPTEKS. Sari (2017) menyatakan bahwa IPA (Ilmu Pengetahuan Alam) secara garis besar berarti suatu cabang ilmu sains yang mempelajari fenomena alam melalui observasi dan menganalisis bukti-bukti empiris sehingga mampu menjabarkan, memprediksi dan memahami fenomena alam tersebut. IPA merupakan ilmu yang pada awalnya diperoleh dan dikembangakan berdasarkan percobaan (induktif) namun pada perkembangan selanjutnya IPA juga diperoleh dan dikembangkan berdasarkan teori (deduktif). Ada dua hal berkaitan yang tidak terpisahkan dengan IPA, yaitu IPA sebagai produk, Pengetahuan IPA yang berupa pengetahuan factual, konseptual, procedural, dan metakognitif, dan IPA sebagai proses yaitu kerja ilmiah. Sulistiowati (2015:22). Sejalan dengan pendapatnya Widura (2018) menyatakan, Pembelajaran IPA diarahkan untuk mengutamakan penelitian dan pemecahan masalah. Pembelajaran IPA dapat diklasifikasikan menjadi tiga bagian, yaitu IPA sebagai produk, proses, dan sikap ilmiah. IPA sebagai produk, adalah hasil-hasil penelitian yang telah ilmuan lakukan dan sudah membentuk konsep yang telah dikaji sebagai kegiatan empiris dan analitis. Sebagai proses, adalah untuk menggali dan memahami pengetahuan tentang alam. Sebagai sikap, adalah sikap ilmiah yang dikembangkan dalam pembelajaran melalui kegiatan ilmiah. Pembelajaran IPA seharusnya diupayakan mengarah pada pencapaian tujuan IPA sehingga terbentuk pengalaman belajar yang lebih bermakna. Sejalan dengan pendapatnya Septiawan (2017) yang menyatakan bahwa Untuk dapat mewujudkan harapan pendidikan IPA, proses pembelajarannya harus menekankan pada pemberian pengalaman langsung kepada siswa untuk mengembangkan kompetensi dan memahami alam sekitar secara ilmiah. Tujuan tersebut dapat tercapai jika pembelajaran IPA diorientasikan pada aktivitas-aktivitas yang mendukung terjadinya pemahaman terhadap konsep, prinsip, dan prosedur dalam kaitannya dengan konteks kehidupan mereka seharihari. Maka dari itu pembelajaran IPA merupakan pembelajaran mengenai ilmu pengetahuan yang 
berkaitan dengan alam semesta melalui pengamatan dan prosedur yang tepat dalam mendapatkan suatu kesimpulan.

Pendidikan berkaitan dengan pembelajaran. Pembelajaran dapat diartikan sebagai suatu upaya mengkondisikan siswa untuk dapat belajar secara efektif. Kegiatan belajar efektif terlihat bahwa ada kegiatan memilih, menetapkan dan mengembangkan metode untuk mencapai hasil yang diinginkan dalam proses pembelajaran yang dilakukan oleh siswa dan guru. Guru dalam pelaksanaan pembelajaran mempunyai tanggung jawab profesional untuk mewujudkan tujuan pendidikan nasional. Guru harus menyajikan pembelajaran yang menarik dan menyenangkan bagi peserta didik agar tercapainya suatu kompetensi dan profesionalisme guru dalam kegiatan pembelajaran. Guru berperan sangat penting dalam kegiatan pembelajaran, karena guru bertanggungjawab terhadap tujuan-tujuan pembelajaran yang ingin dicapai secara optimal. Selain sebagai tenaga pendidik dan pengajar tugas utama guru di sekolah adalah sebagai fasilitator sekaligus motivator. Dalam kegiatan pembelajaran peran guru sebagai fasilitator hendaknya memfasilitasi siswa dalam kegiatan pembelajaran, sedangkan guru sebagai motivator dimaksudkan guru memotivator siswa agar implikasi pembelajaran mengarahkan pada pembelajaran efektif dan efisien. Kegiatan pembelajaran yang dilakukan guru seharusnya dapat memberikan rasa tenang dan nyaman pada siswa, karena akan dapat memberikan daya ingat yang berkepanjangan pada siswa. Ilmu pengetahuan yang disampaikan oleh guru akan dipahami dan dimengerti dengan baik oleh siswa apabila ilmu pengetahuan yang diterima oleh siswa dari gurunya bukan bersifat hafalan tetapi ilmu pengetahuan tersebut melalui sebuah proses pemahaman (Suparman, 2010).

Pembelajaran Ilmu Pengetahuan Alam adalah ilmu pengetahuan yang mempelajari gejala-gejala mulai serangkaian proses yang dikenal dengan proses ilmiah yang dibangun atas dasar sikap ilmiah dan hasilnya terwujud sebagai produk ilmiah yang tersusun atas tiga komponen terpenting berupa konsep, prinsip, dan teori yang berlaku secara universal"(Trianto, 2012 :141). Tujuan pembelajaran IPA di SD selain untuk mengembangkan pengetahuan dan pemahaman konsep-konsep IPA yang bermanfaat dan dapat diterapkan dalam kehidupan sehari-hari, juga mengembangkan keterampilan proses untuk menyelidiki alam sekitar, memecahkan masalah dan membuat keputusan. Oleh sebab itu, tujuan pembelajaran ini hendaknya dapat diwujudkan oleh guru dalam rencana pembelajaran. Samatowa (2010:10)

Berdasarkan hasil observasi yang dilakukan pada 12 November 2019 di SD Gugus 8 Kecamatan Gianyar. Kemampuan siswa dalam mengejar target ketercapaian materi yang diberikan masih belum optimal. Tampak pembelajaran yang dilaksanakan oleh guru terdapat permasalahan dalam proses mengajar di kelas khususnya dalam hal penerapan model dan metode yang digunakan dalam pembelajaran kurang bervariasi, kurangnya penggunaan media pembelajaran, siswa masih kurang mampu dalam menyampaikan pendapatnya, serta kegiatan pembelajaran siswa cenderung hanya mendengarkan penjelasan dari gurunya yang harus dihafalkan, sehingga siswa menjadi malas dan bosan. Keadaan ini menyebabkan pembelajaran IPA berlangsung secara menoton atau kurang bervariasi. Pembelajaran yang berlangsung secara menoton akan membuat siswa merasa bosan dan kurang memperhatikan pelajaran yang sedang disampaikan. Hal ini menunjukkan bahwa proses pembelajaran yang masih dilakukan secara konvensional. Pembelajaran konvensional yang dilakukan secara terus menerus pada siswa menimbulkan masalah yang menyebabkan hasil belajar IPA tidak tercapai dengan optimal.

Untuk mengatasi permasalahan tersebut, diperlukan inovasi dari guru untuk mengemas pembelajaran IPA agar pembelajaran IPA dapat digemari oleh siswa dengan berbantuan Mind Mapping. Perlu diketahui bahwa dengan berbantuan Mind Mapping adalaha cara mencatat yang kreatif, efektif dan secara harfiah akan memenatakan pikiran dan juga merupakan peta rute yang hebat bagi ingatan yang memungkinkan siswa menyusun fakta dan pikiran sedemikian rupa, sehingga cara kerja alami otak dilibatkan sejak awal. Ini berarti membantu siswa dalam mengingat informasi akan lebih mudah dan lebih bisa diandalkan dari pada menggunakan teknik pencatatan tradisional.

Model pembelajaran Think Talk Write diperkenalkan oleh Huinker \& Laughlin. Pada dasarnya pembelajaran ini dibangun melalui proses berpikir, berbicara dan menulis. Strategi pembelajaran Think Talk Write dapat menumbuh kembangkan kemampuan pemecahan masalah. Alur kemajuan pembelajaran Think Talk Write dimulai dari keterlibatan siswa dalam berpikir atau berdialog dengan dirinya sendiri setelah proses membaca, selanjutnya berbicara dan membagi ide dengan temannya sebelum menulis. Suasana ini lebih efektif jika dilakukan dalam kelompok heterogen dengan 3-5 siswa. Dalam kelompok ini siswa diminta membaca, membuat catatan kecil, menjelaskan, mendengarkan dan membagi ide bersama teman kemudian mengungkapkannya melalui tulisan. Aktivitas berpikir, berbicara dan menulis ini adalah salah satu bentuk aktivitas belajar mengajar yang memberikan peluang kepada siswa untuk berpartisipasi aktif. Tahapan-tahapan yang dilakukan dalam pembelajaran menggunakan tipe ini adalah berpikir (Think), berbicara (Talk), dan menulis (Write). 
Berdasarkan uraian latar belakang masalah tersebut, maka dilakukan penelitian yang berjudul “ Pengaruh Model Pembelajaran Think Talk Write Berbantuan Mind Mapping Terhadap Kompetensi Pengetahuan IPA Siswa Kelas V SD. "

\section{METODE PENELITIAN}

Pelaksanaan penelitian pada semester 2 tahun ajaran 2019/2020 di kelas V SD Gugus 8 Kecamatan Gianyar Tahun Ajaran 2019/2020. Jenis penelitian yang dilakukan adalah penelitian kuantitatif dengan desain penelitiannya yaitu desain eksperimen semu (quasi eksperimen design) dan rancangan penelitiannya Non-equivalent post-test only control group design. Untuk mengetahui nilai kompetensi pengetahuan IPA maka nilai akhir IPA siswa digunakan untuk menyetarakan kelompok. Teknik yang digunakan dalam penyetaraan kelompok yaitu menggunakan uji t. Selanjutnya, post-test digunakan untuk mendapatkan data kompetensi pengetahuan IPA kelompok eksperimen dan kelompok kontrol. Populasi dari penelitian ini yakni siswa V SD Gugus 8 Kecamatan Gianyar Tahun Ajaran 2019/2020 yang teridiri dari enam sekolah dasar negeri. Adapun jumlah dari populasi yang menjadi penelitian ini adalah 146 siswa. Agar nantinya hasil penelitian dapat tergeneralisasi dan mewakili seluruh karakteristik populasi maka diperlukan pemilihan sampel penelitian.

Sampel penelitian ini menggunakan teknik Random Sampling yaitu cara pengambilan sebuah sampel, dengan merandom kelas siswa. Seluruh siswa kelas V SD yang ada di Gugus 8 Kecamatan Gianyar dilakukannya pengundian. Pengundian dilakukan sebanyak dua kali untuk memperoleh kelas eksperimen dan kelas kontrol. Pada tahap pertama, menentukan sampel dilakukan dengan cara pengundian yakni dengan menulliskan nama-nama seluruh kelas V yang ada pada masing-masing SDN Gugus 8 Kecamatan Gianyar sehingga semua anggota dari populasi diberikan kesempatan yang sama untuk dipilih dan dijadikan sampel penelitian. Cara undian ini dilakukan dengan menulis nama sekolah pada masing-masing kertas yang jumlahnya 6 sekolah, kemudian kertas tersebut digulung sau persatu kemudian dimasukkan ke dalam kotak selanjutnya dikocok. Setelah dilaksanakan pengambilan dua gulungan kertas maka akan muncul nama-nama dari SD pada kedua gulungan kertas tersebut dan nama-nama SD yang muncul tersebut merupakan sampel penelitian. Tahap kedua, setelah dua kelas terpilih melalui cara pengundian, maka dua sampel tersebut akan dilaksanakan uji kesetaraan untuk mengetahui tingkat kesetaraan kedua kelas yang akan digunakan sebagai kelas eksperimen dan kelas kontrol. Untuk mencari tahu tingkat kesetaraan maka peneliti menggunakan hasil akhir IPA Siswa. Adapun uji prasyarat yang dilakukan terlebih dahulu yaitu uji normalitas sebaran data dengan teknik Kolmogorov-Smirnov dan uji homogenitas varians. Jika kedua kelompok sampel sudah setara maka dapat dilanjutkan dengan memberikan perlakuan.

Metode pengumpulan data yang digunakan penelitian ini adalah metode tes dan instrumen yang digunakan adalah tes pilihan ganda. Instrumen ini digunakan untuk mengukur kompetensi pengetahuan IPA siswa pada dua kelas yang diberikan perlakuan yang berbeda, yaitu kelas eksperimen dan kelas kontrol. Tes merupakan alat yang digunakan untuk mengukur pengetahuan yang dimiliki seorang individu yang kemudian memperoleh suatu hasil atau data. Hal ini diperkuat oleh Agung (2014:89) yang menyatakan bahwa data adalah bahan mentah atau informasi, dapat berupa angka-angka dan kategorikategori mengenai objek tertentu. Data dalam penelitian ini akan dikumpulkan dengan metode tes. Metode tes menurut Agung (2014:92) kaitannya dalam penelitian ini ialah cara memperoleh data yang berbentuk suatu tugas yang harus dikerjakan oleh seseorang atau sekelompok orang yang dites (testee), dan dari tes dapat menghasilkan suatu skor (interval).

Metode analisis data yaitu metode analisis statistik inferensial. Cara analisis data merupakan teknik analisis statistik inferensial serta uji t. Ada dua syarat yang dilalui sebelum uji t yaitu uji normalitas sebaran data serta uji homogenitas varians. Apabila data didapatkan telah terpenuhinya prasyarat uji normalitas serta homogenitas sehingga pada uji hipotesis analisis yang digunakan statistik parametrik. Analisis statistik dipakai yaitu uji beda mean (uji t).

\section{ANALISIS DAN PEMBAHASAN}

Penelitian ini adalah eksperimen dengan memberikan perlakuan pada dua sampel yaitu kelas V SD Negeri 2 Siangan menjadi kelas eksperimen dan kelas V SD Negeri 2 Sumita menjadi kelas kontrol. Pada kelas eksperimen diberikan perlakuan model pembelajaran Think Talk Write berbantuan Mind Mapping sedangkan pada kelas kontrol dibelajarkan secara konvensional. Setiap kelas diberikan perlakuan sebanyak 6 kali dan setelahnya diberikan post-test yang bertujuan untuk mendapatkan data nilai dari setiap sampelnya. Berdasarkan perhitungan yang dilakukan diperoleh nilai mean, standar deviasi dan varians dari data post-test kedua kelompok penelitian sebagi berikut. 
Tabel 1. Deskripsi data Kompetensi Pengetahuan IPA

\begin{tabular}{ccc}
\hline Deskripsi Data & Kelompok Eksperimen & Kelompok Kontrol \\
\hline $\mathrm{N}$ & 25 & 18 \\
Mean & 83,16 & 65,06 \\
Standar Deviasi & 5,15 & 5,62 \\
Varians & 19,86 & 17,90 \\
\hline
\end{tabular}

Berdasarkan Tabel 1. tersebut maka disusun tabel distribusi frekuensi relatif kompetensi pengetahuan IPA siswa pada kelompok kontrol dan kelompok eksperimen berdasarkan hasil post-test yang diperoleh yaitu sebagai berikut.

Tabel 2. Tabel Distribusi Frekuensi Relatif Kompetensi Pengetahuan IPA Kelompok Eksperimen

\begin{tabular}{lll}
\hline $\mathbf{X}$ & $\mathbf{F}$ & $\mathbf{F r}(\mathbf{\%})$ \\
\hline 75 & 1 & $4 \%$ \\
78 & 5 & $20 \%$ \\
80 & 7 & $28 \%$ \\
84 & 1 & $4 \%$ \\
85 & 3 & $12 \%$ \\
87 & 3 & $12 \%$ \\
88 & 1 & $4 \%$ \\
90 & 2 & $8 \%$ \\
93 & 2 & $8 \%$ \\
Jumlah & $\mathbf{2 5}$ & $\mathbf{1 0 0 \%}$ \\
\hline
\end{tabular}

Tabel 3. Tabel Distribusi Frekuensi Relatif Kompetensi Pengetahuan IPA Kelompok Kontrol

\begin{tabular}{ccc}
\hline $\mathbf{X}$ & $\mathbf{F}$ & $\mathbf{F r}(\mathbf{0})$ \\
\hline 52 & 1 & $6 \%$ \\
53 & 1 & $6 \%$ \\
60 & 2 & $10 \%$ \\
63 & 1 & $6 \%$ \\
65 & 2 & $10 \%$ \\
66 & 2 & $10 \%$ \\
67 & 2 & $10 \%$ \\
68 & 2 & $10 \%$ \\
69 & 2 & $10 \%$ \\
70 & 1 & $10 \%$ \\
71 & 1 & $6 \%$ \\
72 & 1 & $6 \%$ \\
Jumlah & $\mathbf{1 8}$ & $\mathbf{1 0 0} \%$ \\
\hline
\end{tabular}

Data yang diperoleh dari penelitian ini kemudian dianalisis dengan beberapa tahapan yaitu uji normalitas, uji homogenitas dan uji hipotesis. Berdasarkan hasil analisis uji normalitas pada kelompok eksperimen, diperoleh nilai maksimum $\left|\mathrm{F}_{\mathrm{T}}-\mathrm{F}_{\mathrm{S}}\right|$ yaitu 0,24 kemudian nilai tersebut dibandingkan dengan $\mathrm{KS}_{\text {tabel }}$ Kolmogorov Smirnov $=0,26$. Hal ini menunjukkan bahwa nilai maksimum $\left|\mathrm{F}_{\mathrm{T}}-\mathrm{F}_{\mathrm{S}}\right|<\mathrm{KS}_{\text {tabel }}$ Kolmogorov Smirnov dapat diartikan data pada hasil kompetensi pengetahuan IPA kelompok eksperimen dikatakan berdistribusi normal.

Hasil analisis uji normalitas pada kelompok kontrol, diperoleh nilai maksimum $\left|\mathrm{F}_{\mathrm{T}}-\mathrm{F}_{\mathrm{S}}\right|$ yaitu 0,31 kemudian nilai tersebut dibandingkan dengan $\mathrm{KS}_{\text {tabel }}$ Kolmogorov Smirnov $=0,31$. Hal ini menunjukkan bahwa nilai maksimum $\left|\mathrm{F}_{\mathrm{T}}-\mathrm{F}_{\mathrm{S}}\right|<\mathrm{KS}_{\text {tabel }}$ Kolmogorov Smirnov dapat diartikan data hasil Kompetensi Pengetahuan IPA kelompok kontrol berdistribusi normal.

Uji homogenitas varians ini dilaksanakan berdasarkan data kompetensi pengetahuan IPA kelompok eksperimen dan kelompok kontrol. Uji homogenitas dilaksanakan agar mengetahui mengenai adanya perbedaan yang dapat terjadi dalam uji hipotesis memang benar bisa terjadi diakibatkan karena ada beda varians diantara kelompok, bukan sebagai akibat perbedaan dalam kelompok. Uji homogenitas varians 
dalam penelitian ini mempergunakan uji F. Varians terbesar yaitu 19,86 dibagi varians terkecil 17,90 sehingga mendapatkan hasil 1,11. Dari hasil analisis, diperoleh $F_{\text {hitung }}=1,11$, hasil ini kemudian dibandingkan dengan harga $F_{\text {tabel }}$ pada derajat kebebasan $(\mathrm{dk})$ untuk pembilang $\mathrm{n} 1-1(25-1=24)$ dan derajat kebebasan $(\mathrm{dk})$ untuk penyebut $\mathrm{n} 2-1(18-1=17)$ diperoleh $\mathrm{F}_{\text {tabel }}=2,19$. Berdasarkan analisis, diperoleh $\mathrm{F}_{\text {hitung }}=1,11$. Hal ini berarti $\mathrm{F}_{\text {hitung }}=1,11<\mathrm{F}_{\text {tabel }}=2,19$ sehingga data kedua kelompok memiliki varians yang homogen.

Hipotesis diuji adalah $\mathrm{H}_{0}$ yaitu tidak ada perbedaan signifikan Tidak terdapat perbedaan yang signifikan Kompetensi Pengetahuan IPA antara kelompok yang dibelajarkan dengan model pembelajaran Think Talk Write berbantuan Mind Mapping dengan kelompok yang dibelajarkan secara konvensional pada kelas V. Sesuai hasil uji normalitas serta homogenitas varians diperoleh data kelompok eksperimen serta kelompok kontrol berdistribusi normal serta homogen. Sesuai penjelasan sebelumnya sehingga uji statistik yaitu uji-t menggunakan polled varians. Dengan kriteria apabila $\mathbf{t}_{\text {hitung }} \leq \mathbf{t}_{\text {tabel, }}$, artinya $\mathrm{H}_{\mathrm{o}}$ diterima dan $\mathrm{H}_{\mathrm{a}}$ ditolak, dan apabila $\mathrm{t}_{\text {hitung }}>\mathrm{t}_{\text {tabel }}$ artinya $\mathrm{H}_{\mathrm{o}}$ ditolak dan $\mathrm{H}_{\mathrm{a}}$ diterima. Pada taraf signifikan $5 \%$ dengan $\mathrm{dk}=\mathrm{n}_{1}+\mathrm{n}_{2}-2$. Rekapitulasi hasil analisis uji t data post-test sebagai berikut

Tabel 4. Hasil Analisis Uji-t Data Post-test

\begin{tabular}{lllllllll}
\hline No & \multicolumn{1}{c}{ Sampel } & $\begin{array}{l}\text { Rata- } \\
\text { rata }\end{array}$ & Varians & $\mathrm{Dk}$ & $\mathrm{N}$ & $\mathrm{t}_{\text {hitung }}$ & $\mathrm{t}_{\text {tabel }}$ & Kesimpulan \\
\hline 1 & Kelas Eksperimen & 83,16 & 19,86 & 41 & 25 & 3,5 & 2,021 & Ho ditolak \\
2 & Kelas Kontrol & 65,06 & 17,90 & & 18 & & & \\
\hline
\end{tabular}

Berdasarkan hasil uji hipotesis dari kompetensi pengetahuan IPA kelompok eksperimen dan kelompok kontrol diperoleh $t_{\text {hitung }}=3,5$ dalam taraf signifikansi $5 \%$ dengan dk $=n 1+n 2-2=25+18-2$ $=41$ menunjukkan nilai $t_{\text {tabel }}=2,021$ sehingga $t_{\text {hitung }}>t_{\text {tabel }}(3,5>2,021) . H_{0}$ yang berbunyi tidak terdapat perbedaan yang signifikan Kompetensi Pengetahuan IPA antara kelompok yang dibelajarkan dengan model pembelajaran Think Talk Write Berbantuan Mind Mapping dengan kelompok yang dibelajarkan secara konvensional pada kelas $\mathrm{V}$ ditolak.

Setelah menganalisis data post-test, maka diperoleh nilai rerata kompetensi pengetahuan IPA kelompok eksperimen yakni 83,16 dan kelompok kontrol yakni 65,06. Hal ini membuktikan bahwa ratarata dari kompetensi pengetahuan IPA kelompok eksperimen ini lebih tinggi dibandingkan dengan nilai rata-rata dari kompetensi pengetahuan IPA dalam kelompok kontrol. Dari hasil pengujian asumsi dikatakan sebaran data kompetensi pengetahuan IPA siswa berdistribusi normal serta mempunyai varians yang homogen, uji hipotesis mempergunakan uji t dengan rumus polled varians.

Hasil penelitian ini juga diperkuat dengan penelitian yang dilakukan oleh Ni Made Ayu Agustina Mas Sriati menunjukkan bahwa model pembelajaran TTW berbantuan media gambar berpengaruh terhadap kompetensi pengetahuan IPA siswa kelas V. Hal tersebut dibuktikan dengan hasil $t_{\text {hitung }}=6,050>$ $\mathrm{t}_{\text {tabel }}=1,980$ pada taraf signifikansi $5 \%$ dengan $\mathrm{dk}=95$. Demikian pula nilai Rerata kompetensi pengetahuan IPA siswa kelompok eskperimen $=82,42>=74,51$ rerata kompetensi pengetahuan IPA siswa kelompok kontrol. Dengan demikian dapat disimpulkan bahwa model pembelajaran TTW berbantuan media gambar berpengaruh terhadap kompetensi pengetahuan IPA siswa kelas V SD Gugus Moch Hatta Denpasar Selatan Tahun Pelajaran 2016/2017.

Penelitian ini juga diperkuat oleh hasil penelitian dari Ni Wayan Eka Widya Lestari (2017) hasil penelitian ini menunjukkan terdapat pengaruh model pembelajaran kooperatif tipe Student Teams Achievement Divisions berbantuan Mind mapping terhadap kompetensi pengetahuan IPA siswa kelas V SD Gugus Kompyang Sujana Denpasara Utara Tahun Ajaran 2016/2017. Hal tersebut diperoleh dari Hasil analisis data diperoleh $t_{\text {hitung }}=3,000>t_{\text {tabel }}=2,000$ untuk signifikansi $5 \%$ dan $d k=77$. Berdasarkan kriteria pengujian, maka H0 ditolak dan Ha diterima. Adapun rata-rata Gain Skor kompetensi pengetahuan IPA pada kelompok yang dibelajarakan dengan model pembelajaran kooperatif tipe Student Teams Achievement Divisions berbantuan Mind mapping adalah 0,56, sedangkan pada kelompok yang dibelajarankan dengan pembelajaran konvensional adalah 0,44. Berdasarkan hasil penelitian tersebut dapat disimpulkan bahwa terdapat pengaruh model pembelajaran kooperatif tipe Student Teams Achievement Divisions berbantuan Mind mapping terhadap kompetensi pengetahuan IPA siswa kelas V SD Gugus Kompyang Sujana Denpasara Utara Tahun Ajaran 2016/2017.

Berdasarkan perolehan hasil kompetensi pengetahuan IPA dinyatakan bahwa kedua dari kelompok sampel penelitian yang mempunyai kemampuan yang sama, kemudian diberi perlakuan melalui model pembelajaran Think Talk Write berbantuan Mind Mapping untuk kelompok eksperimen dan dibelajarkan secara konvensional untuk kelompok kontrol, diperoleh kompetensi pengetahuan IPA yang berbeda. 
Perbedaan yang signifikan kompetensi pengetahuan IPA difaktori oleh perlakuan yang diberikan pada kedua kelompok sampel.

Dalam kelompok eksperimen yang diberikan perlakuan melalui model pembelajaran Think Talk Write berbantuan Mind Mapping dalam kompetensi pengetahuan IPA berjalan dengan kondusif dan optimal. Hal ini disebabkan karena model pembelajaran Think Talk Write berbantuan Mind Mapping memiliki kelebihan yaitu model Think Talk Write membantu dan mendorong siswa untuk berpikir, berbicara, dan kemudian menuliskan suatu topik tertentu. Strategi ini digunakan untuk mengembangkan tulisan dengan lancar dan melatih bahasa sebelum dituliskan. Strategi Think Talk Write memperkenankan siswa untuk memengaruhi dan memanipulasi ide-ide sebelum menuangkannya dalam bentuk tulisan. Ia juga membantu siswa dalam mengumpulkan dan mengembangkan ide-ide melalui percakapan terstruktur. (Hauinker dan Laughlin,2013).

Selama kegiatan pembelajaran siswa dapat lebih aktif karena model pembelajaran Think Talk Write berbantuan Mind Mapping menciptakan lingkungan belajar yang membuat semua siswa aktif berpartisipasi dalam pembelajaran dikelas.

Berbeda dengan kelompok kontrol yang dibelajarankan secara konvensional atau pembelajaran yang biasa dilaksanakan oleh wali kelas. Secara teoritis pembelajaran yang dibelajarkan secara konvensional merupakan proses belajar mengajar dengan cara tradisional atau sering dikatakan sebagai metode yang berceramah, ini dikarenakan sejak lama metode ini sudah dijadikan sebagai alat komunkasi langsung diantara guru dengan peserta didik dalam proses mengajar terlihat bahwa pembelajaran kurang maksimal untuk meningkatkan kompetensi pengetahuan siswa.

Berdasarkan pemaparan tersebut, maka bisa didapat kesimpulan bahwa model pembelajaran Think Talk Write berbantuan Mind Mapping berpengaruh terhadap kompetensi pengetahuan IPA pada siswa kelas V.

\section{KESIMPULAN}

Sesuai dengan hasil analisis data post-test menunjukkan bahwa nilai rata-rata kelompok eksperimen dan kelompok kontrol $(83,16>65,06)$. Dari analisis uji hipostesis dengan uji-t diperoleh $t_{\text {hitung }}$ $=3$,5. Sedangkan pada taraf signifikansi $5 \%$ dan $\mathrm{dk}=25+18-2=41$ maka diperoleh nilai tabel $=2,021$. Karena $t_{\text {hitung }}>t_{\text {tabell }}(3,5>2,021)$ ini berarti $\mathrm{H}_{\mathrm{o}}$ ditolak. Hal ini membuktikan bahwa terdapat perbedaan yang signifikan kompetensi pengetahuan IPA siswa yang dibelajarkan melalui model pembelajaran Think Talk Write berbantuan Mind Mapping dengan kelompok siswa yang dibelajarkan secara konvensional. Jadi diperoleh kesimpulan bahwa model pembelajaran Think Talk Write berbantuan Mind Mapping berpengaruh terhadap kompetensi pengetahuan IPA siswa kelas V SDN Gugus 8 Kecamatan Gianyar Tahun Ajaran 2019/2020.

Sesuai temuan penelitian yang diperoleh, untuk guru, kepala sekolah serta peneliti lainnya supaya siswa dapat mengikuti model pembelajaran Think Talk Write berbantuan Mind Mapping dengan lebih aktif agar siswa mampu memperoleh pengalaman belajar yang lebih bermakna, memberikan masukan bagi kepala sekolah agar dapat dijadikan pedoman bagi sekolah dan pendukung sumber belajar bagi guru sehingga dapat menciptakan kualitas pembelajaran di sekolah dasar, serta agar dijadikan referensi untuk melaksanakan penelitian selanjutnya atau menemukan inovasi kegiatan pembelajaran yang bermakna bagi siswa.

\section{DAFTAR PUSTAKA}

Adhitama, N., Parmin, \& Sudarmin. (2015). IMPLEMENTASI QUANTUM LEARNING BERBANTUAN MIND MAPPING. Unnes Science Education.

Agung, A.A Gede. 2014. Metodologi Penelitian Pendidikan. Yogyakarta: Aditya Media Publishing.

Agung, A.A Gede. 2015. Buku Ajar Evaluasi Pendidikan. Singaraja: Jurusan Teknologi Pendidikan, Fakultas Ilmu Pendidikan Universitas Pendidikan Ganesha

Agung, A.A Gede. 2016. Statistika Dasar untuk Pendidikan. Yogyakarta: Deepublish.

Arikunto, Suharsimi. 2015. Dasar-dasar Evaluasi Pendidikan. Jakarta: Bumi Aksara. 
Ayu Dewayani, Dian. 2016. Model Pembelajaran Think Talk Write (Ttw) Terhadap Hasil Belajarpemecahan Soal Cerita Bilangan Bulat Matematika Siswatunarungu. Jurnal Pendidikan Khusus, Vol.8, No.1.

Buzan (2006). Buku Pintar Mind Mapping. Jakarta: PT Gramedia Pustaka

Cahyono, Tri. 2015. Statisti Uji Normalitas. Purwokerto: Yayasan Sanitarian Banyumas (Yasamas).

Darmawan, Km. Agus. 2017. "Pengaruh Model Pembelajaran Think Talk Write Terhadap Keterampilan Menulis Deskripsi Siswa Kelas V". E-Journal PGSD Universitas Pendidikan Ganesha, Volume 5, No. 2 (diakses tanggal 18 Januari 2018).

Dantes. 2008. Pendidikan Teknohumanistik (Suatu Rangkaian Perspektif dan Kebijakan Pendidikan Menghadapi Tantangan Global). Makalah disampaikan pada seminar pendidikan diselenggarakan oleh S2 Pendas Pps Undiksa, tanggal 22 Agustus 2008.

Dantes. 2012. Metode Penelitian.Yogyakarta: Penerbit Andi.

Dantes, Nyoman. 2017. Analisis ～dan Design Eksperimen. Singaraja Universitas Pendidikan Ganesha.

Darmadi, Hamid. 2014. Metode Penelitian Pendidikan dan Sosial. Bandung: Alfabeta.

Fatkasari, Dyah. 2017. "Pengaruh Model Pembelajaran Kooperatif Tipe Think Talk Write Terhadap Keterampilan Menulis Deskripsi Siswa Kelas IV Sdn Petung Asri 3 Kecamatan Pandaan Kabupaten Pasuruan" Jurusan Pendidikan Guru Sekolah Dasar FIP Universitas Negeri Surabaya, Volume 5, Nomor 3.

Huda, Mifthakul. 2013. Model-model Pengajaran dan Pembelajaran. Jakarta: Pustaka Pelajar

Hartanto. 2017. Penerapan Model Pembelajaran Think Talk Write (TTW) dengan Bantuan Lembar Kerja Siswa untuk Meningkatkan Aktivitas dan Hasil Belajar IPA Terpadu Siswa Kelas VII A SMP Negeri 2 Rantau Panjang. Jurnal Inovasi Dan Pembelajaran Fisika Vol. 4 No. 1 Hal. 10-17. http://fkip.unsri.ac.id/index.php/menu/104.

Juniasih, N. W., Jampel, I. N., \& Setuti, N. M. (2013). Pengaruh Model Pembelajaran Think Talk Write (Ttw) Berbantuan Media Konkret terhadap Hasil Belajar IPA Siswa Kelas IV SD. Jurnal Mimbar PGSD Undiksha.

Kosasih. 2014. Strategi Belajar dan Pembelajaran. Bandung: Yrma Widya

Munawaroh, S., Suratmat, \& Fathani, A. H. (2019). Kemampuan Penalaran Dan Pemecahan Masalah Matematis Melalui Model Pembelajaran (Air) Menggunakan Media Mind Mapping Pada Materi Bilangan Bulat Kelas Vii Smp Shalahuddin Malang. Pendidikan Matematika, 14(8), 91-99.

Putri, Neka Amelia. 2014. Pengaruh Penerapan Model Pembelajaran Kooperatif Tipe Think Talk Write Terhadap Kemampuan Pemecahan Masalah Matematika Siswa Kelas XI IPA Di SMA Negeri 1 Pariaman. Jurnal Pendidikan Matematika, Vol.3, No.3.

Rusman. 2012. Model-Model Pembelajaran : Mengembangkan Profesionalisme Guru, RajaGrafindo Persada, Jakarta.

Riski, Riska, Muh. Rizal, Linawati. 2017. Penerapan Model Pembelajaran Kooperatif Tipe Think Talk Write (TTW) untuk Meningkatkan Hasil Belajar Siswa pada Materi Hubungan Sudut Pusat, Panjang Busur, dan Luas Juring di Kelas VIII C SMP Negeri 9 Palu. Jurnal elektronik Pendidikan Matematika Tadulako, Volume 5 Nomor 2, Hal. 175-190. Tersedia Pada: http://jurnal.untad.ac.id/jurnal/index.php/JEPMT/article/view/9097. 
Sumarmo, Utari dkk. 2012. KEMAMPUAN DAN DISPOSISI BERPIKIR LOGIS, KRITIS, DAN KREATIF MATEMATIK (Eksperimen terhadap Siswa SMA Menggunakan Pembelajaran Berbasis Masalah dan Strategi Think-Talk-Write). Jurnal Pengajaran MIPA. Vol. 17, No.1.

Sugiarti, Ln. L. P. Y., Putra, I. K. A., \& Abadi, I. . G. S. (2014). Pengaruh model pembelajaran ttw ( think talk write ) berbantuan media gambar berseri terhadap keterampilan menulis Bahasa Indonesia siswa kelas V SD Gugus 1 Kecamatan Kediri tahun ajaran 2013 / 2014. E-Journal MIMBAR PGSD Universitas Pendidikan Ganesha.

Saragih, R. 2010. Upaya Meningkatkan Kemampuan Komunikasi Dan Hasil Belajar Matematika Siswa Dengan Menggunakan Strategi Belajar ThinkTalk-Write Pada Topik Kaidah Pencacahan Di Kelas XI SMA Negeri 4 Medan Tahun Ajaran 2010/2011. Skripsi S1 UNIMED

Simanjuntak, M. 2012. Upaya Meningkatkan Hasil Belajar Siswa pada Sub Pokok Bahasan Penjumlahan dan Pengurangan Bilangan Bulat dengan Think-Talk-Write (TTW) berbantuan Garis Bilangan 2011/2012. Skripsi S1 UNIMED

Simanjuntak, M. 2014. Peningkatan Kemampuan Representasi dan Komunikasi Matematis Siswa SMP pada Materi Transformasi dengan Think Talk Write (TTW) berbantuan Kartu Domino di Kelas VII SMP Negeri 3 Tebing Tinggi. 2014. Thesis S2 UNIMED

Setiyaningrum, Erin, dan Istiqomah. 2015. Efektivitas Penerapan Model Pembelajaran Think - Talk Write terhadap Prestasi Belajar Matematika Siswa Kelas VII SMP Negeri 3 Magelang. UNION: Jurnal Pendidikan Matematika Vol 3 No 1 Hal. 9-16. Tersedia Pada: http://jurnal.ustjogja.ac.id/index.php/union/article/view/270.

Sugiarta, Sang Made.(2017)."Pengaruh Model Pembelajaran TTW Berbantuan Media Lingkungan terhadap Penguasaan Kompetensi Pengetahuan IPA Siswa Kelas IV". E-Journal Mimbar PGSD Universitas Pendidikan Ganesha,(online),Volume 5,Nomor 2.

Shoimin, Aris. 2014. 68 Model Pembelajaran Inovatif dalam Kurikulum 2013. Yogyakarta: AR-RUZZ Media.

Suandi, Nengah, dkk. 2016. Buku Pedoman Penulisan Karya Ilmiah. Singaraja: Universitas Pendidikan Ganesha.

Sugiyono. 2017. Metode Penelitian. Bandung: Alfabeta.

Sugiyono. 2018. Metode Penelitian Pendidikan. Bandung: Alfabeta.

Yosefa, B., \& Nurjanah, E. 2014. Pengaruh Metode Pembelajaran Quantum Teaching Dengan Menggunakan Mind Mapping Terhadap Kemampuan Penalaran Matematis Pada Siswa.Jurnal Pengajaran Matematika Dan Ilmu Pengetahuan Alam, 18(2), 146. https://doi.org/10.18269/jpmipa.v18i2.2PSI, 1-17. 